Y. SU, ${ }^{1}$ J. MA, ${ }^{2}$ L. F. DU, ${ }^{1}$ J. XIA, ${ }^{1}$ Y. WU,,${ }^{1}$ X. JIA,${ }^{1}$ Y. G. CAI,,${ }^{1}$ Y. H. LI,${ }^{1}$ J. ZHAO, ${ }^{1}$ and Q. LIU ${ }^{1}$

\title{
EVALUATION OF NEONATAL BRAIN DEVELOPMENT USING ACOUSTIC RADIATION FORCE IMPULSE IMAGING (ARFI)
}

\author{
Received March 23, 2014
}

We applied acoustic radiation force impulse imaging (ARFI) for examination of the brains of 41 neonatal infants of different gestational ages. We used a new technical index, Virtual Touch tissue quantification (VTQ), to evaluate elastic properties of the brain tissues. Different brain tissues demonstrated different values of this index. The greater the gestational age, the higher the VTQ value. We conclude that ARFI provides a new quantitative index to evaluate the level of neonatal brain development and increases the objectivity and reliability of clinical analysis. The method is noninvasive, safe, simple, convenient, and can be extensively applied in clinics.

Keywords: neonatal infants, brain development, acoustic radiation force impulse imaging.

\section{INTRODUCTION}

Within the neonatal period, brain tissue and cerebral functions are in the process of development. Because of the existence of a variety of diseases, brain development can be blocked or impaired. Brain damage resulting from a number of reasons can cause functional and structural abnormalities, e.g., clinical manifestations of cerebral palsy, epilepsy and other neurological diseases [1-3]. The data of head ultrasound examination for objective diagnosis of neonatal cerebral diseases is of great significance. The echo intensity in cerebral ultrasound observations provides information on the brain size, width of the gyri, and other characteristics, which can help one to prognose mature conditions of the neonatal brain development and to present different characteristics related to both norm and pathology [4-7]. At the same time, how to quantify sufficiently accurately the respective changes to guide the evaluation of the degree of brain development is still a clinical problem remaining to be resolved [8-10]. Acoustic radiation force impulse imaging (ARFI) is a relatively novel sophisticated technique for evaluating the maturity of the infant brain. At present, ARFI has been widely used for examinations of the liver, kidneys, thyroid, breast,

${ }^{1}$ Department of Ultrasound and Newborn Pediatrics, Shanghai First People's Hospital, School of Medicine, Shanghai Jiaotong University, Shanghai, China. ${ }^{2}$ Department of Cardiovascular Ultrasound, Shanghai East Hospital Affiliated to the Tongji University, Shanghai, China.

Correspondence should be addressed to L. F. Du

(e-mail: yjlfcn@126.com). pancreas, and so on [11-16]. At the same time, ARFI has been used for examination of the brain to a limited extent.

We have quantitatively analyzed neonatal cerebral white and gray matters within different gestational ages using Virtual Touch tissue quantification (VTQ) of ARFI, and here we discuss the value of VTQ to evaluate certain aspects of neonatal brain development.

\section{METHODS}

Patients. We examined 41 newborns from the Department of gynecology and obstetrics of the First Hospital affiliated to the Shanghai Jiaotong University. In this group, there were 22 boys and 19 girls; gestational ages were $<37$ weeks ( 16 cases) and $\geq 37$ weeks ( 25 cases). All neonates were classified with respect to their gestational ages (AGA) using the respective scale. The exclusion criteria were jaundice of the newborn, aspiration pneumonia, neonatal brain injury, pregnancy complicated with diabetes mellitus, pregnancy-induced hypertension, anemia, and heart and lung diseases.

Acquisition of the ARFI. Real-time ARFI was performed using the Siemens Acuson S2000 diagnostic ultrasound system (Siemens Medical Solutions, Germany) equipped with a $4 \mathrm{C} 1(3.5 \mathrm{MHz})$ probe. All examinations were performed in succession by two independent sonographers. Both of them had more than ten years experience in ultrasonic scanning. They 


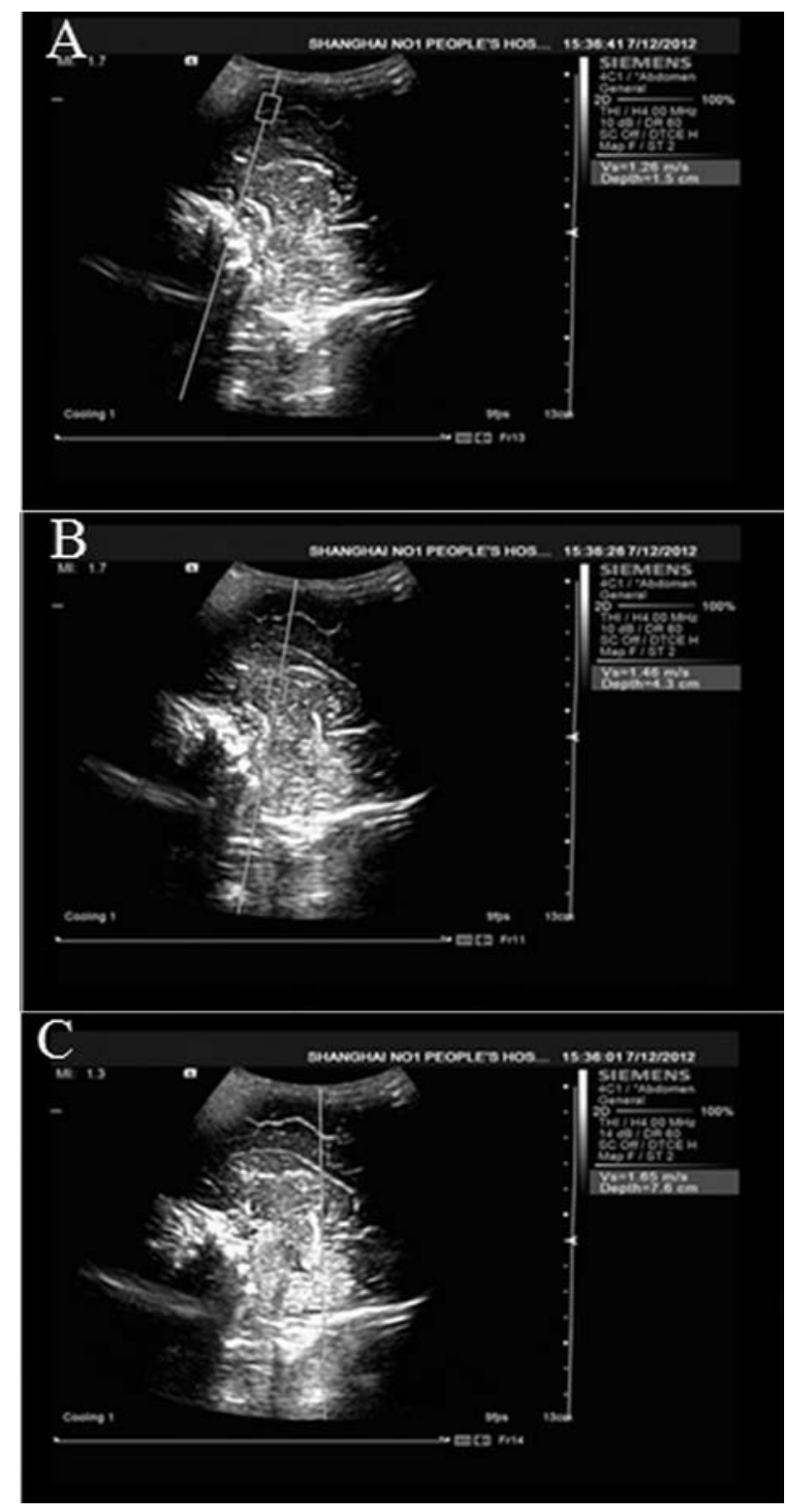

F i g. 1. Value of VTQ of different parts of the brain in a full-term infant. A) Parietal white matter, $1.26 \mathrm{~m} / \mathrm{sec} ; B$ ) thalamic and basal ganglia, $1.46 \mathrm{~m} / \mathrm{sec}$, and $C$ ) cerebellum, $1.65 \mathrm{~m} / \mathrm{sec}$.

P и с. 1. Значення VTQ у різних частинах мозку доношеного новонародженого.

were blinded to the findings and physical examination results when performing.

Conventional Ultrasound. Neonates 1 to 3 days old were held in a supine position in a quiet state. All participants were examined by brain US using the anterior fontanelle as the acoustic window. Conventional sonography was used to observe the skull continuity (brain midline centered), brain parenchyma, and lateral ventricle and to measure the cerebral transverse diameter, width of the lateral ventricle, and width of the superior frontal gyrus. A color Doppler technique was used to access the blood supply of the brains, including the middle cerebral artery, anterior cerebral artery, posterior cerebral artery, and vertebral basilar artery.

ARFI. An ARFI elastic model, VTQ, was used to measure the elasticity of neonatal cerebral white and gray matters, which included the parietal white matter, thalamic nuclei, basal ganglia, cerebellum, hippocampus, medulla oblongata, and cerebral falx.

Virtual Touch Tissue Quantification. In the VTQ model, a ROI $(5 \times 10 \mathrm{~mm})$ was placed inside the brain, and the depth of the ROI was less than $80 \mathrm{~mm}$. All the structures of the newborn brain could be observed. To measure more accurately and objectively derived elastic parameters, operators were asked to handle the probe on the cranial surface with special care and accuracy. The measurements were repeated three times randomly, and the average value $(\mathrm{m} / \mathrm{sec})$ was calculated for the VTQ index.

Statistical Analysis. For all statistical analysis procedures, we used SPSS (version 17.0) software (SPSS Inc, USA). All measured data were presented as means \pm s.d. The groups of premature and fullterm infants were compared using the Student's test and analysis of variance. $P<0.05$ was considered an indication of statistically significant intergroup difference.

\section{RESULTS}

Echo Intensity Quantitative Analysis. We used VTQ to quantitatively analyze the echo intensity in different parts of the brain tissues. It was found that the mean value of VTQ of the parietal white matter was $1.34 \pm$ $\pm 0.33 \mathrm{~m} / \mathrm{sec}$, that of the thalamic and basal ganglia was $1.53 \pm 0.35 \mathrm{~m} / \mathrm{sec}$, that of the cerebellum was $1.62 \pm 0.31 \mathrm{~m} / \mathrm{sec}$, and that of the cerebral falx was $2.23 \pm 0.48 \mathrm{~m} / \mathrm{sec}$ (Fig. 1 A-C).

We measured the value of VTQ of the echo intensity in different parts of brain tissues in the examined infants of different gestational ages. As was observed, the VTQ value of the parietal white matter, thalamic and basal ganglia, cerebellum, and cerebral falx increased gradually with increased gestational age. The values of VTQ of preterm infants were significantly lower than those of full-term infants $(P<0.05)$ (Table 1 ; Fig. 2). 


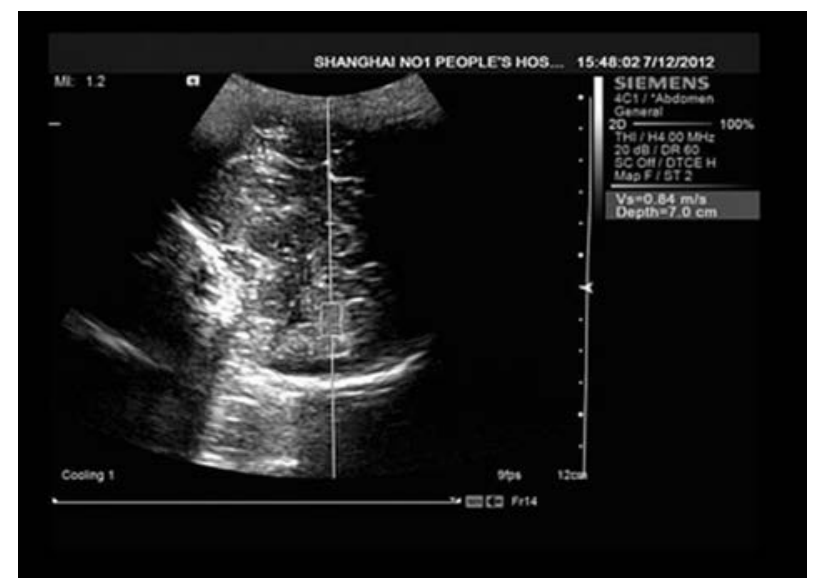

F i g. 2. The value of VTQ of the cerebellum in a preterm infant $(0.84 \mathrm{~m} / \mathrm{sec})$.

Р и с. 2. Значення VTQ у мозочку недоношеного новонародженого.

\section{DISCUSSION}

ARFI is a new elastic sound imaging technology. It uses the acoustic radiation force to fire a pulse and to cause instantaneous $(<1 \mathrm{sec})$ and tiny micron-value displacements in the ROI of the body. At the same time, it produces a shear wave at transverse vibrations. Using a computer, it is possible to test and calculate the speed of the shear wave (shear wave velocity). This shear wave velocity depends on elastic properties of the tissue. The higher the shear wave velocity, the greater the coefficient of elasticity. The virtual touch tissue quantification (VTQ) of ARFI allows researchers to measure these parameters more objectively [1721]. We successfully used this technology to evaluate quantitatively the echo intensity in the neonatal brain.

Our study using echo-intensity quantitative analysis demonstrated that tissues of different brain parts in full-term infants showed the following mean values of VTQ. In the parietal white matter, this was $1.34 \pm 0.33 \mathrm{~m} / \mathrm{sec}$, in the thalamic and basal ganglia, $1.53 \pm 0.35 \mathrm{~m} / \mathrm{sec}(114 \%)$, in the cerebellum,
$1.62 \pm 0.31 \mathrm{~m} / \mathrm{sec}(121 \%)$, and in the cerebral falx, $2.23 \pm 0.48 \mathrm{~m} / \mathrm{sec}(166 \%)$. The observed regularity of increase was in accordance with the sequence of brain development. This provides a more intuitive understanding of the situation with the echo intensity in different brain tissues.

The CNS is an ectodermal derivative. Myelination of brain tissues takes place at about 20 weeks of gestational age. The development goes, in general, from the bottom to the top, from central to peripheral regions, from dorsal to ventral parts, and from the sensory systems to the motor ones. In other words, the development of myelination in the brain goes from the brainstem to the thalamic and basal ganglia, and to the cortical hemispheres. It suggests that the development and maturation of the thalamus occur earlier than those of the cortex [22, 23].

Our results showed that the brain echo intensities are dissimilar at different gestational ages. The values of VTQ in preterm infants were obviously lower than those in full-term infants. Thus, this index, similarly to other indices, demonstrates with certainty that the brains of preterm infants are more immature than those of full-term infants [24, 25].

Neonatal head ultrasound examination is performed using the anterior and lateral anterior fontanelle as the acoustic windows for obtaining cerebral coronal and sagittal scans. The advantages of this technique are the following: bed check, no radiation damage, low cost, no need for the patient to be calm, and the possibility to be repeated many times. It is the first choice for diagnosing premature infant brain injury. Adequate experience of the operator is necessary, and there are certain limitations related to craniocerebral peripheral lesions. Therefore, such examination should be combined with some other imaging examination methods (such as MRI) [26, 27].

To sum up, the value of VTQ is a very useful quantitative index in the evaluation of the peculiarities of the neonate brain development. ARFI is a safe,

Comparison of VTQ values between preterm and full-term infants

Порівняння значень VTQ у недоношених та доношених новонароджених

\begin{tabular}{l|c|c|c}
\hline \multirow{2}{*}{ Position } & \multicolumn{3}{c}{ VTQ (m/sec) } \\
\cline { 2 - 4 } & $<37$ weeks & $\geq 37$ weeks & $<$ \\
\hline Parietal white matter & $1.12 \pm 0.43$ & $1.34 \pm 0.33$ & $<0.05$ \\
Thalamic nuclei & $1.21 \pm 0.51$ & $1.53 \pm 0.35$ & $<0.05$ \\
Cerebellum & $1.33 \pm 0.41$ & $1.62 \pm 0.31$ & $<0.05$ \\
Cerebral falx & $1.95 \pm 0.52$ & $2.23 \pm 0.48$ & $<0.05$ \\
\hline
\end{tabular}

Footnote: means \pm s.d. are shown. 
noninvasive, simple, and convenient technology; it can play a greater role not only in the evaluation of the neonate brain development, but also in diagnosing diseases of the neonate brain (including preterm and full-term infants). While AFRI is still at a preliminary clinical application stage, it is obvious that we must observe more cases and accumulate experience.

Acknowledgements. We want to thank the pediatricians who provided clinical data for us. We thank Xia Jin, Fang Min, Gao LinLin, et al. (the Newborn Department of Pediatrics of our hospital) for their helpful contributions.

This study was conducted in accordance with the declaration of Helsinki. This study was conducted with approval from the Ethics Committee of the Shanghai First People's Hospital, School of Medicine, Shanghai Jiaotong University. Written informed consent was obtained from all parents and responsible physicians before ARFI examination.

The authors of this communication, Y. Su, J. Ma, L. F. Du, J. Xia, Y. Wu, X. Jia, Y. G. Cai, Y. H. Li, J. Zhao, and Q. Liu, confirm the absense of any conflict related to comercial or financial interests, to interrelations with organizations or persons in any way involved in the research, and to interrelations of the co-authors.

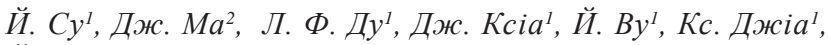
Й. Г. Каi ${ }^{1}$, Ю. Х. Л ${ }^{1}$, Дж. Жао ${ }^{1}$, К. Лю ${ }^{1}$

\section{ОЦІНКА РОЗВИТКУ МОЗКУ НОВОНАРОДЖЕНИХ ІЗ ВИКОРИСТАННЯМ ВІЗУАЛІЗАЦІЇ ЕФЕКТІВ СИЛО- ВИХ ІМПУЛЬСІВ АКУСТИЧНОГО ВИПРОМІНЮВАННЯ (ARFI)}

${ }^{1}$ Шанхайська перша народна лікарня Медичного факультету Шанхайського університету Джяотонг, Шанхай (Китай).

${ }^{2}$ Шанхайська східна лікарня при Університеті Тонгджі, Шанхай (Китай).

P е 3 ю м е

Досліджували результати візуалізації впливу силових імпульсів акустичного випромінювання (ARFI), вивчаючи головний мозок 41 новонародженого 3 різними термінами гестації. Ми використовували новий технічний індекс Virtual Touch Quantification (VTQ) для оцінки еластичних властивостей тканин мозку. У різних тканин мозку значення даного індексу були відмінними. Ми дійшли висновку, що методика ARFI дозволяє отримати новий кількісний показник для оцінки ступеню розвитку неонатального мозку; це збільшує об'єктивність та надійність клінічних аналізів. Метод є неінвазивним, безпечним, простим та зручним i може знайти широке застосування в клініці.

\section{REFERENCES}

1. N. Salmaso, S. Tomasi, and F. M. Vaccarino, "Neurogenesis and maturation in neonatal brain injury," Clin. Perinatol., 41, 229-239 (2014).

2. S. H. Kwon, L. Vasung, L. R. Ment, and P. S. Huppi, "The role of neuroimaging in predicting neurodevelopmental outcomes of preterm neonates," Clin. Perinatol., 41, 257-283 (2014).

3. J. A. Dipietro, K. T. Kivlighan, K. A. Costigan, et al., "Prenatal antecedents of newborn neurological maturation," Child Dev., 81, 115-130 (2010).

4. M. Eldib, A. N. Massaro, D. Bulas, and H. Aly, "Neuroimaging and neurodevelopmental outcome of premature infants," Am. J. Perinatol., 27, 803-818 (2010).

5. L. M. Leijser, N. Vos, F. J. Walther, and G.van WezelMeijler, "Brain ultrasound findings in neonates treated with intrauterine transfusion for fetal anaemia," Early Human Dev., 88, 717-724 (2012).

6. R. K. Pooh, "Neurosonoembryology by three-dimensional ultrasound," Semin. Fetal Neonat. Med., 17, 261-268 (2012).

7. A. H. Whitaker, J. F. Feldman, J. M. Lorenz, et al., "Neonatal head ultrasound abnormalities in preterm infants and adolescent psychiatric disorders," Arch. Gen. Psychiat., 68, 742-752 (2011).

8. L. Catte, B. Keersmaeker, and F. Claus, "Prenatal neurologic anomalies: sonographic diagnosis and treatment," Paediatr. Drugs, 14, 143-155 (2012).

9. W. M. Gerdavan, J. S. Sylke, and M. L. Lara, "Cranial ultrasonography in neonates: Role and limitations," Seminars Perinatol., 34, 28-38 (2010).

10. F. P. Nelly, E. Goya, J. Tomas, et al., "Quantitative tissue echogenicity of the neonatal brain assessed by ultrasound imaging," Ultrasound Med. Biol., 35, 1421-1426 (2009).

11. Y. J. Su, L. F. Du, Y. Wu, et al., "Evaluation of cervical cancer detection with acoustic radiation force impulse ultrasound imaging," Exp. Ther. Med., 5, 1715-1719 (2013).

12. G. Cui, Z. Yang, W. Zhang, et al., "Evaluation of acoustic radiation force impulse imaging for the clinicopathological typing of renal fibrosis," Exp. Ther. Med., 7, 233-235 (2014).

13. X. J. Hou, A. X. Sun, X. L. Zhou, et al., "The application of Virtual Touch tissue quantification (VTQ) in diagnosis of thyroid lesions: a preliminary study," Eur. J. Radiol., 82, 797801 (2013).

14. M. A. Mateen, K. A. Muheet, R. J. Mohan, et al., "Evaluation of ultrasound based acoustic radiation force impulse (ARFI) and eSie touch sonoelastography for diagnosis of inflammatory pancreatic diseases," JOP, 13, 36-44 (2012).

15. W. Meng, G. Zhang, C. Wu, et al., "Preliminary results of acoustic radiation force impulse (ARFI) ultrasound imaging of breast lesions," Ultrasound Med. Biol., 37, 1436-1443 (2011).

16. M. T. Shuang, Z. Ping, Q. Ying, et al., "Usefulness of acoustic radiation force impulse imaging in the differential diagnosis of benign and malignant liver lesions," Acad. Radiol., 18, 810815 (2011).

17. J. R. Doherty, J. J. Dahl, and G. E. Trahey, "Harmonic tracking of acoustic radiation force-induced displacements," IEEE Trans. Ultrason. Ferroelectr. Freq. Control, 60, 2347-2358 (2013).

18. J. Zhan, X. H. Diao, Q. L. Chai, and Y. Chen, "Comparative study of acoustic radiation force impulse imaging with realtime elastography in differential diagnosis of thyroid nodules," Ultrasound Med. Biol., 39, 2217-2225 (2013). 
19. I. Sporea, O. H. Gilja, S. Bota, et al., "Liver elastography - an update," Med. Ultrason, 15, 304-314 (2013).

20. S. Wojcinski, K. Brandhorst, G. Sadigh, et al., "Acoustic radiation force impulse imaging with Virtual Touch ${ }^{\mathrm{TM}}$ tissue quantification: mean shear wave velocity of malignant and benign breast masses," Int. J. Womens Health, 30, 619-627 (2013).

21. M. Sugitani, Y. Fujita, Y. Yumoto, et al., "A new method for measurement of placental elasticity: acoustic radiation force impulse imaging," Placenta, 34, 1009-1013 (2013).

22. O. Kenichi, M. Susumu, K. D. Pamela, et al., "Multi-contrast human neonatal brain atlas: Application to normal neonate development analysis," NeuroImage, 56, 8-20 (2011).

23. C. M. Herba, S. J. Roza, P. Govaert, et al., "Infant brain development and vulnerability to later internalizing difficulties: the generation R study," J. Am. Acad. Child Adolesc. Psychiat., 49, 1053-1063 (2010).

24. S. J. Steggerda, F. T. de Bruïne, V. E. Smits-Wintjens, et al., "Ultrasound detection of posterior fossa abnormalities in full-term neonates," Early Human Dev., 88, 233-239 (2012).

25. B. Helen, P. Chryssoula, N. Ioannis, et al., "Comparison of findings on cranial ultrasound and magnetic resonance imaging before discharge in preterm infants. Correlation with the neurological examination," Early Human Dev., 86, S29 (2010).

26. B. Gross, D. Garcia-Tapia, E. Riedesel, et al., "Normal canine brain maturation at magnetic resonance imaging," Vet. Radiol. Ultrasound, 51, 361-373 (2010).

27. N. Tusor, T. Arichi, S. J. Counsell, and A. D. Edwards, "Brain development in preterm infants assessed using advanced MRI techniques," Clin. Perinatol., 41, 25-45 (2014). 